\title{
Protein chemists favour automatic answers
}

David Adam, London

British biologists say that a lack of investment in high-throughput technology for solving protein structures is hindering their progress in structural genomics.

In a report sent to the government's research councils and the Wellcome Trust at the end of last month, 102 biologists argue that limited access to robotic equipment that rapidly expresses, purifies and crystallizes proteins is leaving them behind in the scientific race to exploit gene-sequence information.

"If the UK community does not develop and adopt new technologies within a relatively short space of time, it will lose leadership in some of the most exciting and rewarding areas of biology," says Neil Isaacs, a structural biologist at Glasgow University. "There is a rapidly growing discrepancy between the level of access to such technology in the UK compared to that in the US, Japan and, to a lesser extent, Europe."

The biologists call for up to $\mathfrak{E} 50$ million (US\$72 million) to be spent on infrastructure for structural genomics over the next five years. But Isaacs says that the report is not just a demand for money, but is intended to inform the government ahead of this summer's comprehensive spending review.

Structural genomics is often defined as an effort to determine the structures of all of the proteins expressed in a genome, or a region

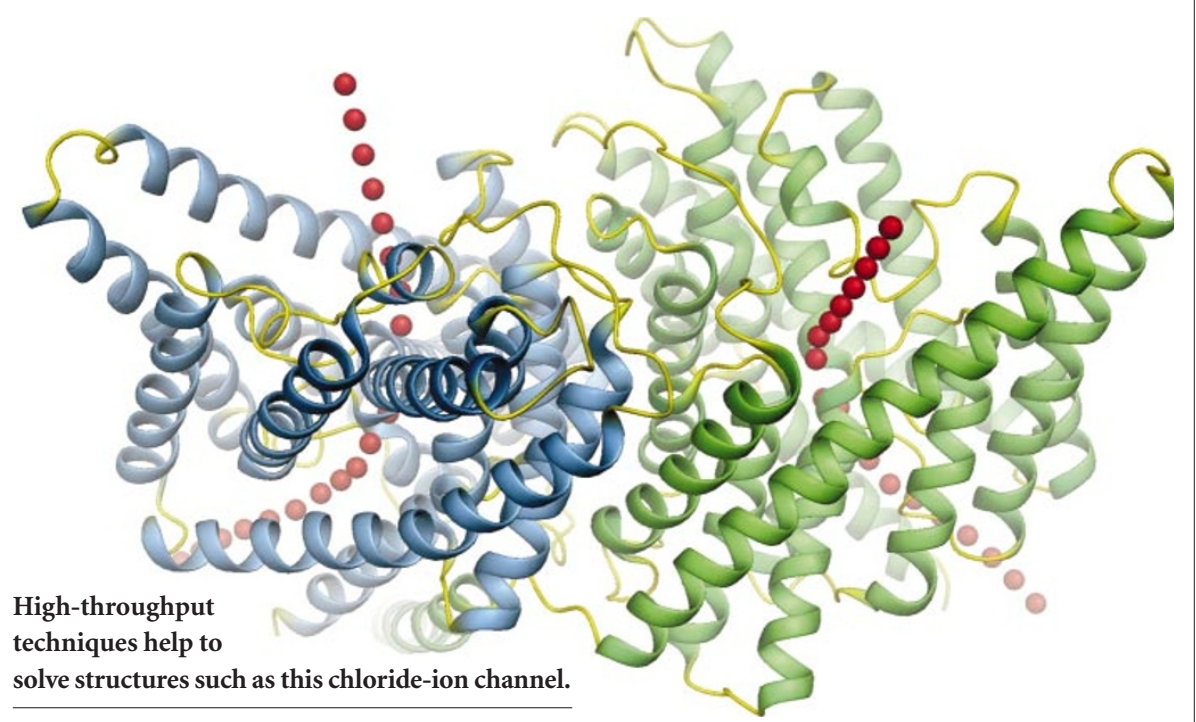

of a genome. Sceptics say, however, that a blanket approach is inefficient, as it is likely to yield many worthless structures. Richard Henderson of the Medical Research Council's Laboratory for Molecular Biology at Cambridge University, for example, says that what he terms "intelligent structural biology" might prove to be more productive.

But Isaacs says that high-throughput techniques can bring a powerful approach to certain problems, such as those involving target proteins that are difficult to crystallize.
He cites the recent solving of the structure of a protein in chloride-ion channels (see Nature $415,287-294 ; 2002$ ), which he says could not have been done without automation.

Colin Miles, head of biomolecular sciences at the Biotechnology and Biological Sciences Research Council (BBSRC), says the council has already commissioned a review of Britain's needs for structural genomics. "Given the size and scale of the requirements in this field, it is obvious that a more considered approach is required," he says.

\section{Japan set to endorse Kyoto Protocol as Bush flies in}

David Cyranoski, Tokyo

The Japanese government has made its strongest statement yet in support of ratification of the Kyoto Protocol.

The statement, issued by a working group on global warming chaired by the prime minister, Junichiro Koizumi, says that Japan should "pursue the approval of the Kyoto Protocol and passage of relevant bills for its establishment" during this session of its parliament, the Diet, which ends on 19 June.

The working group also encouraged the amendment of an energy-efficiency law and the creation of a new law to promote the use of electricity from renewable sources.

The statement, which could open the way for Japan and Europe to implement the protocol without the support of the United States, was issued as US President George W. Bush arrived in Japan, having just released his own, minimalist strategy for dealing with climate change (see page 821).

"As soon as possible, we want to push forward with the ratification of the treaty and with the establishment of the means for

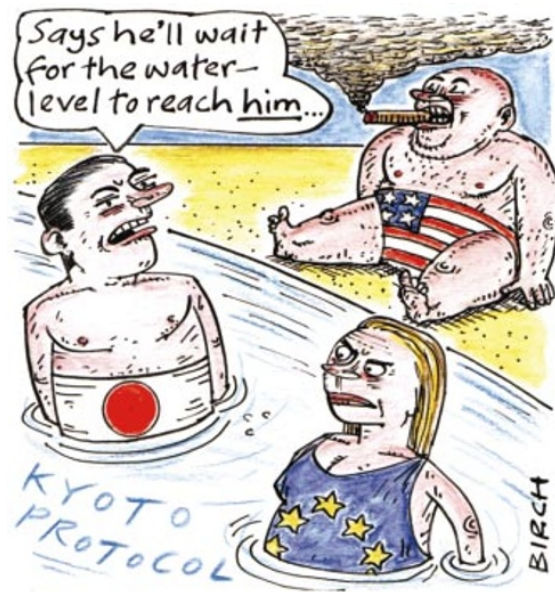

achieving the goals," says Hiroshi Ohki, Japan's environment minister.

Ohki says he hopes that the United States will still participate in the Kyoto treaty, although he also approves of the latest US effort to "create a concrete plan of their own".

Questions remain about Japan's readiness to make genuine cuts in its carbon emissions. The powerful Keidanren industrial group has lobbied with apparent success against laws that would impose such cuts, and against taxes on emissions.

"Industrial groups like Keidanren have pushed for voluntary measures," says Ohki. "Whereas the focus of the US plan is on voluntary compliance, in Japan there will be a mix of both compulsory and voluntary measures," he says. The first phase of the protocol, in 2002-04, will depend mainly on voluntary compliance, according to officials at Japan's economic ministry.

Some Japanese researchers are also sceptical about the treaty's actual impact. "The wide range of uncertainty, in things like absorption of $\mathrm{CO}_{2}$ by forests, has become a tool of negotiation," says Syukuro Manabe, of the Frontier Research System for Global Change in Tokyo. "As far as I can tell, the Kyoto Protocol hasn't shown us how to deal with these problems."

Ratification "could be an embarrassment, if Japan joins and then just keeps missing targets," says another researcher, at the National Institute of Environmental Studies in Tsukuba. 